\title{
CHANGE OF NUTRIENT CONTENTS OF TEAK SEEDLINGS (TECTONA GRANDIS LINN F.) UNDER DIFFERENT COMPOST TREATMENTS
}

\author{
M.A. Lankathilaka and S.M.C.U.P. Subasinghe \\ Department of Forestry and Environmental Science, University of Sri Jayewardenepura, Sri Lanka \\ Email: madhushanasanak@yahoo.com, Tel: +947 73797531
}

\begin{abstract}
The present study was conducted to identify the changes in nutrient contents in teak seedlings with the application of different types of nutrients along with compost. Compost was applied as compost alone, compost with calcium (Dolomite), with phosphorus (Triple Supper Phosphate, i.e, TSP) and with both calcium and phosphorus (Dolomite and TSP). In order to identify the nutrient changes; nitrogen, phosphorus, potassium, magnesium and calcium concentrations in leaves of teak seedlings under different treatments were analysed before and after 3 months of compost application. According to the results, nitrogen content in leaves of all treatments after 3 months of application were lower than that in leaves before the application of compost. The differences in phosphorus and potassium concentrations in leaves were the highest when compost was applied with TSP. The highest magnesium concentration was also observed under compost treatment with TSP. Among all the treatments, higher calcium differences were observed when compost was applied with both TSP and Dolomite, compost with Dolomite and compost with TSP respectively. The above observations showed that the application of different types of compost affect the nutrient contents of teak plants in different manner. However, application of compost with TSP showed the highest amounts of both potassium and magnesium amounts and a higher calcium amounts in plants.
\end{abstract}

\section{INTRODUCTION}

Nutrient requirement of plants are fulfilled mainly by the available nutrients in soil. Nutritional elements required for the successful growth and reproduction of plants are called essential elements for plants (Green et al., 1997). Those essential elements can be categorized as macro elements and micro elements. Essential macro elements include C, H, O, N, P, K, Mg, Ca and S (Hesse, 1971).

However, the nutrient content for plants may vary depending on the quality of soil. Moreover due to some characteristics of soil, nutrients may not be available for plants though they are present in the soil. Therefore soil type and fertility plays an important role in supplying the required plant nutritions and thereby affects the growth of plants. However, in the situations where the required plant nutritional elements are lack in soils, these have to be provided externally. This is usually done by fertilization.

Enhancing and maintaining soil fertility is an important factor as the main objective in commercial forest plantations is to achieve the desirable growth in plants within short period of time,. This may become more important in plantations established in lands with poor soil quality. Usually this requirement is fulfilled by the addition of inorganic fertilizer in most of the plantations. However, application of inorganic fertilizer requires an additional cost and also some of the chemical properties of soil alter with the long term application of inorganic fertilizer. In contrast to that, application of organic fertilizer (compost) associates with less cost and environmental damage compared to the inorganic fertilizers. The nutrient content in compost can vary according to the raw materials used. Studying the effect of application of compost mixed with important inorganic fertilizer is important in this context.

A portion of the total uptake of various nutrients is accumulated in the non-photosynthesis tree biomass and the rate of uptake reaches the maximum at the early stages of growth. The high

Proceedings of the $15^{\text {th }}$ International Forestry and Environment Symposium, 26-27 November 2010.

Published by Department of Forestry and Environmental Science, University of Sri Jayewardenepura, Sri Lanka. 
growth rate in early years is due to the rapid increase in foliage biomass and high concentration of nutrients found not only in foliage but also in young stem and branches.

With attainment of the maximum foliage biomass, the demand for nutrients by new foliage can, in a large measure, be met by translocation from older tissue (Miller, 1989). Therefore young leaves have to be analyzed in order to identify the nutrient amounts in the young plants.

\section{MATERIALS AND METHODS}

Application of compost for the present study was done in different methods for two months old teak plants as a field experiment in the Karambewewa teak estate in Puttlam district.

The compost used for this experiment had been produced by mixing cow dung, gliricidia and paddy straw. The nutrient contents and the tested physical properties of the compost used for the experiment is given in table 2.1

Table 2.1: Some properties of the compost used in this study

\begin{tabular}{lc}
\hline Parameter & Amount \\
\hline Moisture content & $21.0 \%$ \\
Organic carbon & $6.5 \%$ \\
Nitrate nitrogen & $14.9 \mathrm{ppm}$ \\
Phosphorus & $13.4 \mathrm{ppm}$ \\
Potassium & $27.4 \mathrm{ppm}$ \\
Magnesium & $2.7 \mathrm{ppm}$ \\
Calcium & $6.7 \mathrm{ppm}$ \\
$\mathrm{pH}$ & 6.8 \\
\hline
\end{tabular}

\subsection{SELECTED COMPOST APPLICATION METHODS}

Compost was applied to plants mainly in two different methods as surface application and as mixing with soil. Under surface application, 4 different types of compost were applied as compost with calcium (dolomite), compost with phosphorus (triple supper phosphate, i.e, TSP), compost with calcium and phosphorus (dolomite and TSP) and compost alone. The same types were used for the compost mixed with soil.

\subsection{ARRANGEMENT OF COMPOST APPLICATION}

According to the section 2.1, there were 8 different compost applications used for the particular study. Other than these applications, there was a control where compost was not applied. 10 plants were used for each treatment. Altogether there were 90 plants in compost trial. Table 2.2 describes the arrangement of compost application.

Table 2.2: Arrangement of plants

\begin{tabular}{lllll}
\hline Application & C only & C+ D & C + TSP & C+ D+ TSP \\
\hline Surface application & 10 plants & 10 plants & 10 plants & 10 plants \\
Mixed with soil & 10 plants & 10 plants & 10 plants & 10 plants \\
\hline
\end{tabular}

$* \mathrm{C}=$ compost, $\mathrm{D}=$ Dolomite 


\subsection{APPLICATION OF COMPOST}

Compost application was done at the beginning of the dry period of the Puttlam area after southwest monsoon period $\left(10^{\text {th }}\right.$ March 2010). For each plant, $6 \mathrm{~kg}$ of compost was applied (except control) either as a surface application or mixed with soil. Dolomite was the source for Calcium. $65 \mathrm{~g}$ of dolomite per plant was applied in the relevant treatments. Triple supper phosphate was the phosphate source used and $16 \mathrm{~g}$ of phosphate per plants was applied.

\subsection{MAINTENANCE OF PLANTS}

In dry periods, seedlings were watered with $4 l$ once in 3 days. Manual weeding was done whenever necessary during the study period.

\subsection{NUTRIENT ANALYSIS OF LEAF SAMPLES OF COMPOST TRIAL}

From each compost treatment, $3^{\text {rd }}$ leaf of $2^{\text {nd }}, 5^{\text {th }}$ and $9^{\text {th }}$ seedlings was collected at the beginning of compost application and after 4 months of compost application.

Total nitrogen $(\mathrm{N})$ content in leaves were determined in micro-Kjeldahl method. The phosphorus $(\mathrm{P})$ contents in the leaf extracts were measured using a spectrophotometer by a colorimetric method. The potassium $(\mathrm{K})$, magnesium $(\mathrm{Mg})$ and calcium $(\mathrm{Ca})$ concentrations were obtained by atomic absorption spectrophotometer.

\section{RESULTS AND DISCUSSION}

Results of the analysis of leaf nutrient contents are given in the table 3.1. The average differences of $\mathrm{N}, \mathrm{P}, \mathrm{K}, \mathrm{Ca}$ and $\mathrm{Mg}$ are shown in the figure 3.1 to 3.5 respectively.

Table 3.1: Average values of nutrients $(\mathrm{ppm})$ in leaves from plants under all treatments

\begin{tabular}{|c|c|c|c|c|c|c|c|c|c|c|}
\hline \multirow[t]{2}{*}{ Treatment } & \multicolumn{2}{|c|}{$\begin{array}{l}\text { Nitrogen } \\
\text { (ppm) }\end{array}$} & \multicolumn{2}{|c|}{$\begin{array}{l}\text { Phosphorus } \\
\text { (ppm) }\end{array}$} & \multicolumn{2}{|c|}{$\begin{array}{l}\text { Potassium } \\
(\mathrm{ppm})\end{array}$} & \multicolumn{2}{|c|}{$\begin{array}{l}\text { Calcium } \\
(\mathrm{ppm})\end{array}$} & \multicolumn{2}{|c|}{$\begin{array}{l}\text { Magnesium } \\
(\mathrm{ppm})\end{array}$} \\
\hline & $1^{\text {st }}$ & $5^{\text {th }}$ & $1^{\mathrm{st}}$ & $5^{\text {th }}$ & $1^{\text {st }}$ & $5^{\text {th }}$ & $1^{\text {st }}$ & $5^{\text {th }}$ & $1^{\text {st }}$ & $5^{\text {th }}$ \\
\hline T1-C (S) & 4.35 & 3.26 & 2.17 & 2.64 & 36.10 & 273.70 & 0.00 & 27.00 & 97.77 & 149.87 \\
\hline $\mathrm{T} 2-\mathrm{C}(\mathrm{M})$ & 4.69 & 3.24 & 1.96 & 2.53 & 34.66 & 297.87 & 0.60 & 19.97 & 86.30 & 243.87 \\
\hline $\mathrm{T} 3-\mathrm{C}+\mathrm{TSP}(\mathrm{S})$ & 5.25 & 3.61 & 2.38 & 4.98 & 37.93 & 313.53 & 1.37 & 9.00 & 86.07 & 189.40 \\
\hline $\mathrm{T} 4-\mathrm{C}+\mathrm{TSP}(\mathrm{M})$ & 5.57 & 2.76 & 2.33 & 3.20 & 36.00 & 419.80 & 0.53 & 8.67 & 81.27 & 373.73 \\
\hline $\mathrm{T} 5-\mathrm{C}+\mathrm{D}(\mathrm{S})$ & 4.02 & 3.24 & 2.17 & 2.83 & 30.06 & 214.53 & 1.77 & 17.73 & 101.73 & 157.93 \\
\hline T6-C + D (M) & 4.10 & 3.12 & 2.09 & 2.45 & 33.93 & 274.07 & 2.67 & 35.33 & 123.43 & 160.40 \\
\hline $\mathrm{T} 7-\mathrm{C}+\mathrm{TSP}+\mathrm{D}(\mathrm{S})$ & 4.36 & 2.94 & 2.41 & 2.89 & 37.99 & 274.50 & 1.33 & 14.67 & 120.00 & 129.67 \\
\hline $\mathrm{T} 8-\mathrm{C}+\mathrm{TSP}+\mathrm{D}(\mathrm{M})$ & 4.50 & 3.52 & 1.96 & 2.66 & 28.00 & 252.13 & 0.97 & 15.40 & 102.63 & 110.80 \\
\hline Control & 5.00 & 3.44 & 2.17 & 2.42 & 32.30 & 250.60 & 9.00 & 4.33 & 118.77 & 181.20 \\
\hline
\end{tabular}

$* \mathrm{C}=$ compost, $\mathrm{D}=$ Dolomite, $\mathrm{M}=$ mixed with soil, $\mathrm{S}=$ surface application

\subsection{DIFFERENCE IN N CONCENTRATION IN LEAVES DUE TO DIFFERENT COMPOST APPLICATIONS}

According to the figure 3.1, the $\mathrm{N}$ content in leaves of all treatments after 3 months of application was lower than that of leaves before the application of compost. However, the higher in $\mathrm{N}$ content reduction was observed in T4 (compost with TSP mixed with soil) compared to the other treatments. 
According to Mangan et al., (undated) the quantity of nitrogen released from any type of organic fertilizer depends on composition of the material, particularly $\mathrm{C} / \mathrm{N}$ ratio and weather. When the $\mathrm{C} / \mathrm{N}$ ratio in compost is much higher, microbial action on further decomposition occurs in compost. When microbial decomposition occurs, microbes must take some extra nitrogen from material for growth and multiplication of their cells. If the nitrogen content is less in compost applied to the plants, this nitrogen requirement would be fulfilled by absorbing nitrogen from soil. Because of that, nitrogen content in soil decreases with the further decomposition of compost. This might be a reason for reduction of nitrogen content in soil with the application of compost.

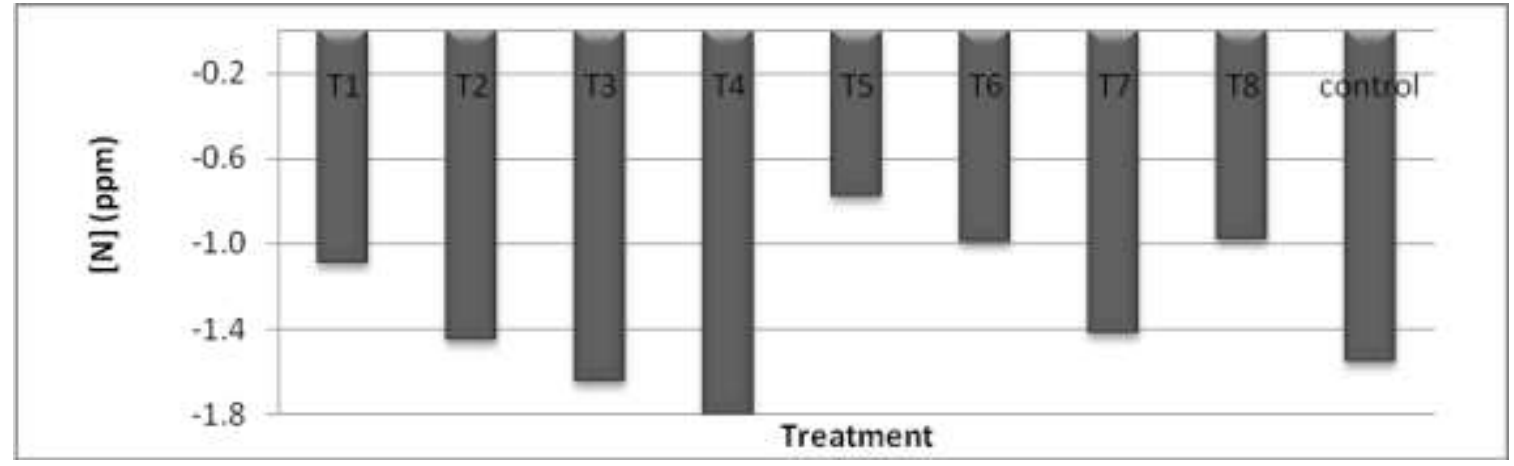

Figure 3.1: $\quad$ Average difference of $\mathrm{N}$ concentration of leaves in all treatments

\subsection{DIFFERENCE IN P CONCENTRATION IN LEAVES DUE TO DIFFERENT COMPOST APPLICATIONS}

According to the figure 3.2, the difference in $\mathrm{P}$ concentration in leaves was the highest in $\mathrm{T} 3$ (compost with TSP as a surface dressing). The rest of the treatments had more or less equal $\mathrm{P}$ amounts.

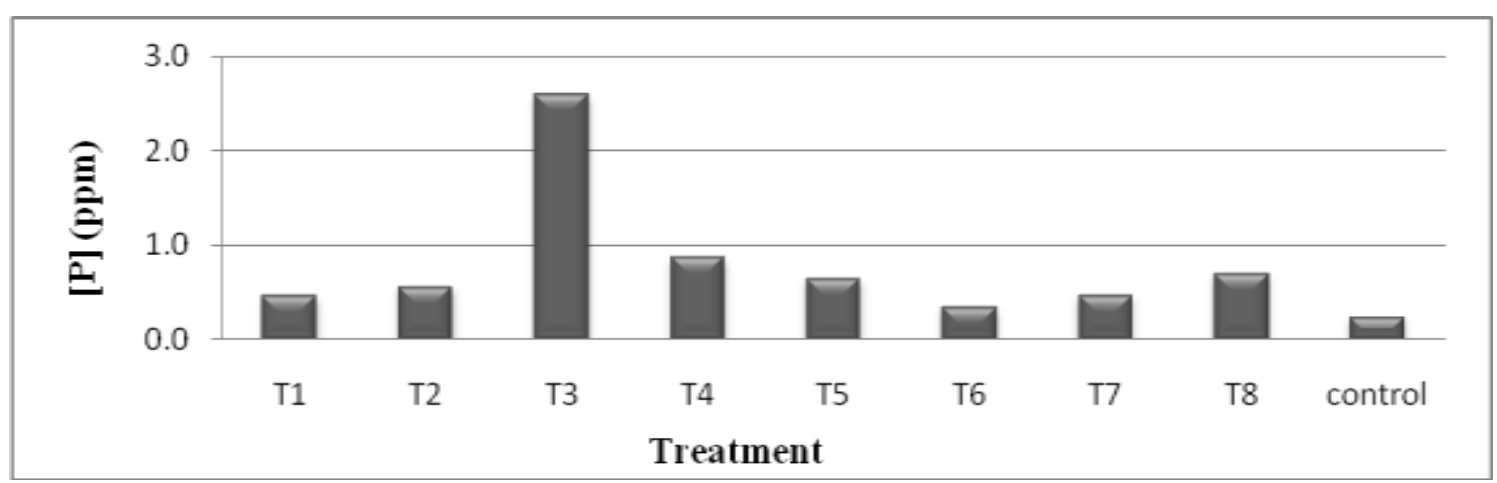

Figure 3.2: $\quad$ Average difference of $P$ concentration of leaves in all treatments

\subsection{DIFFERENCE IN K CONCENTRATION IN LEAVES}

According to the figure 3.3, the highest difference in $\mathrm{K}$ concentration was observed in $\mathrm{T} 4$ (compost with TSP mixed with soil). The difference of $\mathrm{K}$ concentrations in leaves was similar of the rest of the treatments. 


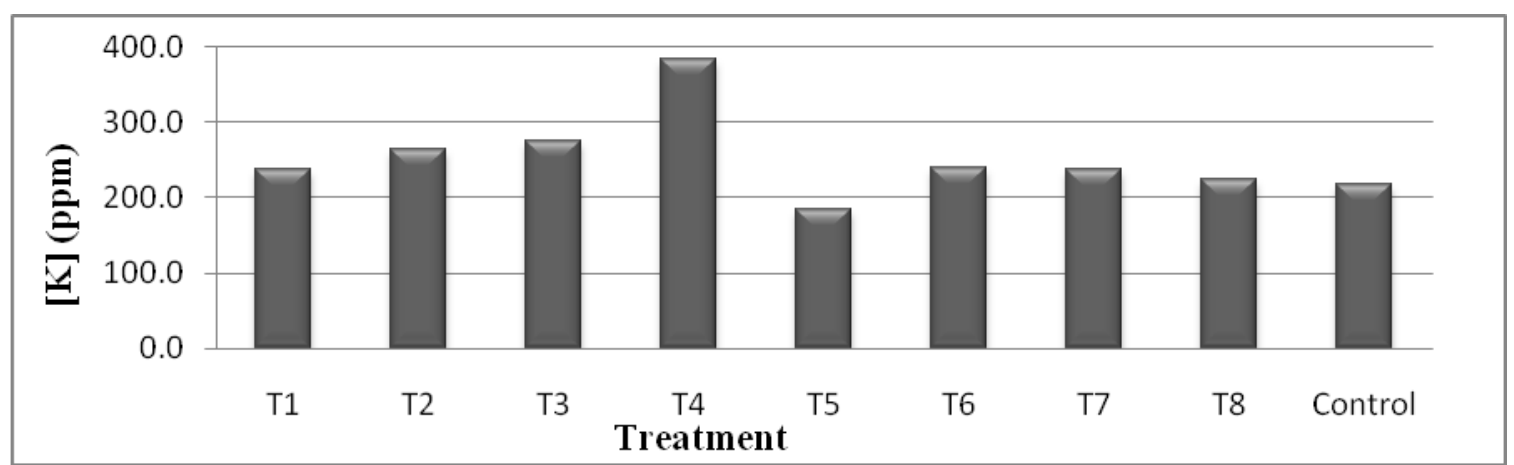

Figure 3.3: $\quad$ Average difference of $\mathrm{K}$ concentration of leaves

Rehmg and Schimitt (1997) mentioned that K in soil becomes more available to plants when the moisture content of soil increases. However, similar water amounts were added to all plants therefore moisture content significantly affects to the results. Therefore higher $\mathrm{K}$ concentrations were observed due to higher moisture content.

\subsection{DIFFERENCE IN MG CONCENTRATION IN LEAVES DUE TO DIFFERENT COMPOST APPLICATIONS}

The figure 3.4 shows the average values of $\mathrm{Mg}$ concentration of leaves from all treatments. According to that, differences in $\mathrm{Mg}$ concentrations showed a variation. The highest $\mathrm{Mg}$ concentration was observed under T4 (compost with TSP mixed with soil).

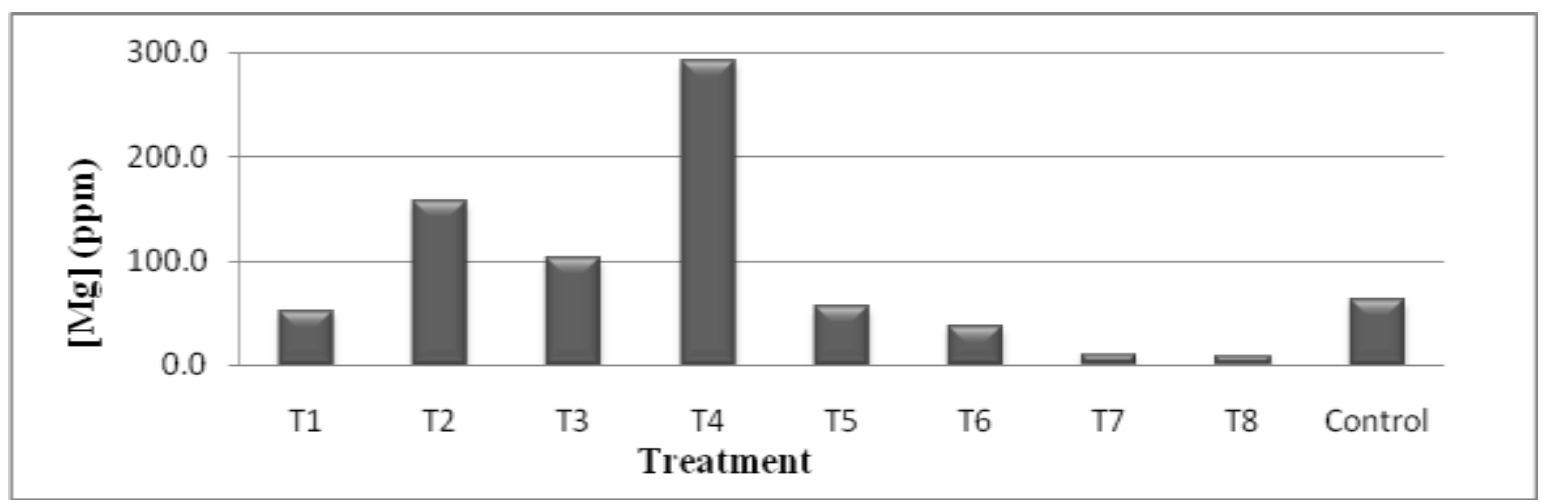

Figure 3.4: $\quad$ Average difference of $\mathrm{Mg}$ concentration of leaves in all treatments

\subsection{DIFFERENCE IN CA CONCENTRATION IN LEAVES DUE TO DIFFERENT COMPOST APPLICATIONS}

According to the figure 3.5, the highest Ca differences were observed in $\mathrm{T} 7$ (compost with TSP and Dolomite as a surface dressing), T6 (compost with dolomite mixed with soil), T4 (compost with TSP mixed with soil) and T3 (compost with TSP as a surface dressing) respectively. There was no difference in T5 (compost with dolomite as a surface dressing) and T8 (compost with TSP and Dolomite mixed with soil). 


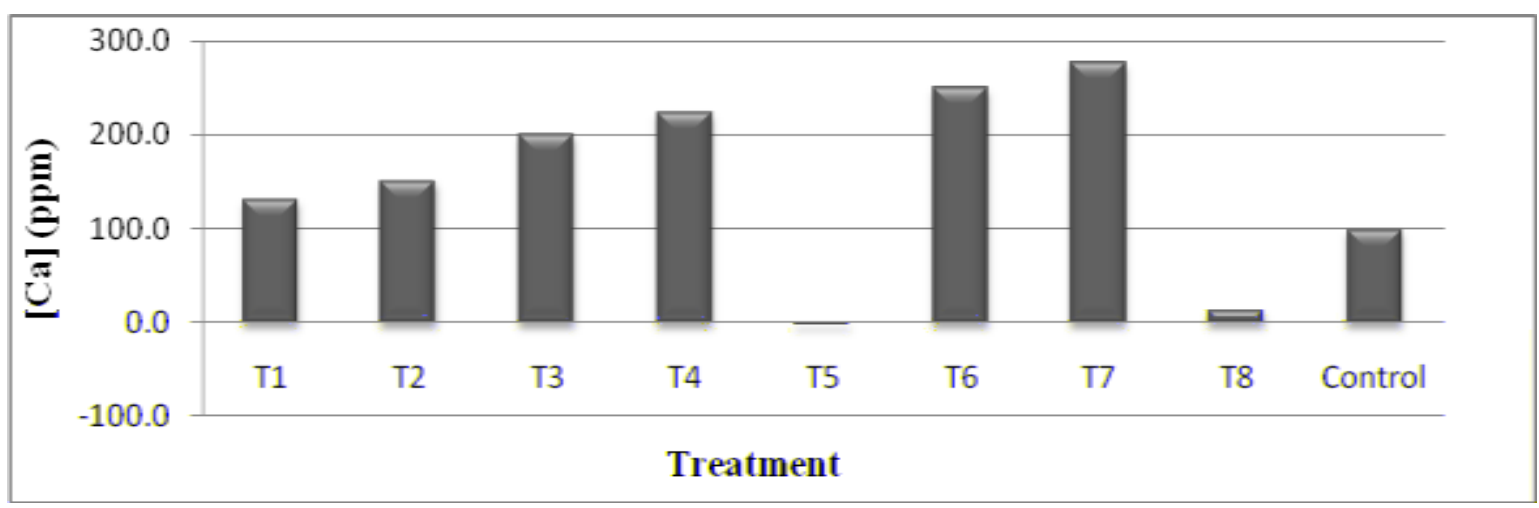

Figure 3.5: Average difference of calcium concentration of leaves in all treatments

This showed that adding dolomite by mixing it with soil was more effective than surface application of dolomite.

\section{CONCLUSION}

According to the results, the highest increment in phosphorus concentration was found in compost with TSP as surface application. The highest increment in potassium and magnesium concentrations was found in compost with TSP mixed with soil and the highest increment in calcium concentration was found in compost with TSP and dolomite added by mixed with soil. According to these results; compost mixed with TSP shows highest increments in phosphorus, potassium and magnesium concentrations and higher calcium concentration.

\section{ACKNOWLEDGEMENT}

Financial support provided by the Sadaharitha Plantations Limited is acknowledged.

\section{REFERENCES}

Bushman, L., Lamb, J., Gyles, R., George, R., and Michael, S., 2002. The nature of phosporus in soil. Availabe from: www.extension.umn.edu/distribution/oc6795.html [Accessed on 15.08.2010]

Green, N.P.O., Stout, G.W. and Taylor, D.J., 1997. Biological Science (3 ${ }^{\text {rd }}$ edition). Press syndicate, University of Cambridge, UK.

Hepler, K.P., 2005. 'Calcium: A central regulator of plant growth and development. The plant cell. Published by American Society of Plant Biologist.vol. 17:2142-2155.

Hesse, P.R., 1971. A Text Book of Soil Chemical Analysis, John Murvan Publishers, London, UK.

Mangan, F., Barker, A., Steven, B. and Peter, B., (undated). Compost use and soil fertility. Availabe from: www.umassvegetable.org/soil - [Accessed on 15.08.2010]

Miller, H. G., 1989. Internal and external cycling of nutrients in forest stands. In: Pereira, J.S. and Landsberg, J.J. (Editors), Biomass production by fast growing trees. Kluwer academic Publishers, The Netherlands.

Rehmg, K. and Schmitt, M. 1997. K for crop production. Availabe from: www.extension.edu/distribution/cropsystems/dcb794.html [Accessed on 20.08.2010] 